\title{
Taxation and Budget Reform Commission (TBRC) Constitutional Amendment 4: Property Tax Exemption of Perpetually Conserved Land; Classification and Assessment of Land Used for Conservation ${ }^{1}$
}

Rodney L. Clouser²

A series of 16 fact sheets has been written on statutory and constitutional proposals adopted by the Taxation and Budget Reform Commission (TBRC). The publications in this series can be accessed at http://edis.ifas.ufl.edu. Fact sheets FE733 through FE741 address statutory changes and fact sheets FE742 through FE748 address constitutional amendments. These fact sheets should not be considered as an all-inclusive assessment of the statutory or constitutional changes recommended by the Taxation and Budget Reform Commission. Some details of proposed changes may not have been discussed due to space limitations. These fact sheets are not intended as a replacement for personal knowledge about actual or proposed changes but are a guide to inform the public on the issues.

\section{Introduction}

According to Article XI, Section 6 of the Florida Constitution, "Beginning in 2007 and each twentieth year thereafter there shall be established a taxation and budget reform commission." The Taxation and
Budget Reform Commission (TBRC) is charged with the following:

examine the state budgetary process, the revenue needs and expenditure processes of the state, the appropriateness of the tax structure of the state, and governmental productivity and efficiency; review policy as it relates to the ability of state and local government to tax and adequately fund governmental operations and capital facilities required to meet the state's needs during the next twenty-year period; determine methods favored by the citizens of the state to fund the needs of the state, including alternative methods for raising sufficient revenues for the needs of the state; determine measures that could be instituted to effectively gather funds from existing tax sources; examine constitutional limitations on taxation and expenditures at the state and local level; and review the state's comprehensive planning, budgeting and needs assessment processes to

1. This is EDIS document FE743, a publication of the Food and Resource Economics Department, Florida Cooperative Extension Service, Institute of Food and Agricultural Sciences, University of Florida, Gainesville, FL. Published July 2008. Please visit the EDIS website at http://edis.ifas.ufl.edu.

2. Rodney L. Clouser, professor and extension public policy specialist of the Food and Resource Economics Department, Florida Cooperative Extension Service, Institute of Food and Agricultural Sciences, University of Florida, Gainesville, FL.

The Institute of Food and Agricultural Sciences (IFAS) is an Equal Opportunity Institution authorized to provide research, educational information and other services only to individuals and institutions that function with non-discrimination with respect to race, creed, color, religion, age, disability, sex, sexual orientation, marital status, national origin, political opinions or affiliations. U.S. Department of Agriculture, Cooperative Extension Service, University of Florida, IFAS, Florida A. \& M. University Cooperative Extension Program, and Boards of County Commissioners Cooperating. Larry Arrington, Dean 


\section{determine whether the resulting information adequately supports a strategic decision-making process.}

The TBRC can make statutory recommendations to the Florida Legislature and directly place proposed constitutional amendments on the ballot for approval or rejection by Florida voters.

Fact sheets in this series will present information on constitutional amendments the TBRC has placed on the fall 2008 general election (2008 November presidential election) ballot. The commission was charged with holding public meetings to carry out their responsibilities and has been meeting since March of 2007. The committee concluded their work and transmitted their proposed constitutional amendments to the Florida Secretary of State on April 28,2008 . All the proposed constitutional amendments required an affirmative vote of at least two-thirds of the voting members of the commission (17 members). In total, the TBRC approved eleven constitutional proposals. The committee combined these eleven proposals into seven constitutional amendments. The amendments passed by the TBRC will be numbered Amendments 3 through 9 on the fall ballot (Amendments 1 and 2 are reserved for two other 2008 amendment proposals, one approved by the legislature and the other a citizen initiative).

The TBRC amendments placed on the 2008 general election ballot are listed by ballot title below:

- Amendment 3: Changes and Improvements Not Affecting the Assessed Value of Residential Real Property

- Amendment 4: Property Tax Exemption of Perpetually Conserved Land; Classification and Assessment of Land Used for Conservation

- Amendment 5: Eliminating State Required School Property Tax and Replacing with Equivalent State Revenues to Fund Education

- Amendment 6: Assessment of Working Waterfront Property Based upon Current Use

- Amendment 7: Religious Freedom
- Amendment 8: Local Option Community College Funding

- Amendment 9: Requiring 65 Percent of School Funding for Classroom Instruction; State's Duty for Children's Education

Each fact sheet in this series will provide details regarding one of the amendments, submitted to the Secretary of State, in the order they will appear on the ballot (Amendment 3, Amendment 4, Amendment 5, Amendment 6, Amendment 7, Amendment 8, and Amendment 9).

\section{Proposed Amendment 4}

When people go to their polling places in November 2008, they will see information on the amendment, references to the portion of the constitution that will be altered, sponsor of the amendment, the ballot title, and the ballot summary. The information for Amendment 4 will be similar or identical to the following and the ballot title and ballot summary are direct quotes:

Proposed Constitutional Amendment No. 4: CONSTITUTIONAL AMENDMENT ARTICLE VII, SECTIONS 3 AND 4 ARTICLE XII, SECTION 28 (Taxation and Budget Reform Commission)

Ballot Title: PROPERTY TAX EXEMPTION OF PERPETUALLY CONSERVED LAND; CLASSIFICATION AND ASSESSMENT OF LAND USED FOR CONSERVATION

\section{Ballot Summary: Requires legislature to} provide a property tax exemption for real property encumbered by perpetual conservation easements or other perpetual conservation protections, defined by general law. Requires legislature to provide for classification and assessment of land used for conservation purposes, and not perpetually encumbered, solely on the basis of character or use. Subjects assessment benefit to conditions, limitations, and reasonable definitions established by general law. Applies to property taxes beginning in 2010. 


\section{Effect of Amendment 4}

Amendment 4 is a combination of two constitutional proposals that were approved by the TBRC. The first component of the amendment extends an ad valorem property tax exemption to owners of real property (land) committed in perpetuity for conservation purposes, including conservation easements. The definition of conservation purposes will be defined in general law (state statute) by the legislature.

The second component of Amendment 4 requires that land used for conservation purposes be classified based on its use rather than a fair market value or a highest and "best use" value. This component of the amendment is similar to how agricultural land is currently assessed and taxed within the state. If approved, both changes would take effect on January $1,2010$.

\section{Impact of Amendment 4}

There is no estimate of the financial cost(s) of this amendment at the current time. Several benefits, however, have been identified with conservation lands. Those benefits include tax breaks for the property owner, open space, reduction in congestion, wildlife habitat, water recharge, etc. Many of these benefits have both direct and indirect impacts. For example, the individual owner of real property with a conservation easement in perpetuity receives a direct benefit in terms of a tax exemption. The property owner might also receive a direct non-financial benefit from being able to observe wildlife directly on the property. Other people, without access, indirectly might benefit from wildlife diversity in the area although they are unable to directly observe that wildlife.

Landowners and others may want to know what the tax exemption will be worth in dollar amounts, but there is no way to know until a taxable value is placed on the property. However, knowledge of the millage rate, combined with the amount of reduction in taxable value as a potential result of the proposed tax exemption, provides some idea of the benefit to the landowner (millage rate is the tax rate per $\$ 1000$ of taxable value). The combined millage rate would include the tax rates for all units of local government (county, city, school boards, and special districts). Assume a typical combined millage rate in Florida might be $\$ 20$ per $\$ 1000$ of value. Using this example, for every $\$ 1000$ per acre reduction in taxable value of the property, the owner would pay $\$ 20$ less in taxes. A reduction in taxable value of $\$ 5000$ per acre would result in a tax savings to the landowner of $\$ 100$ per acre. Property owners willing to commit to perpetual conservation programs for large acreages could save thousands of dollars in taxes under this amendment.

Since this amendment affects ad valorem property taxes, its potential negative impact would fall initially on local units of government (counties, cities, school boards, and special districts). If the proposed amendment is passed, it does not become effective until January 1, 2010. This implies local units of government would not be impacted until fiscal year 2010-2011. Units of local government may be concerned about programs that remove value from tax rolls. Without raising millage rates value removed from the tax roll results in the local unit of government having less tax revenue to provide local government services. If the millage rate is raised, tax revenue might remain constant. The recouping of the potential decline in revenue is shifted to property owners who do not have land in perpetual conservation programs. In general, the thought is that tax payments for other real property owners would only increase a small amount.

Stat staff analysis notes the support of land conservation programs by Florida's state government and residents. It is estimated that almost 9.8 million acres in the state are in governmental (federal, state, county, and municipal) or private conservation land. This is over $27 \%$ of the state's entire land base.

One might ask a number of questions to arrive at a position on the proposed amendment. How much land does the state, counties, and municipalities need in conservation uses? How much value will be removed from tax rolls of local units of government? Will the tax exemption be large enough of an incentive to encourage landowners to place conservation lands under protection in perpetuity? Will landowners be willing to pay more in property taxes to fund the program? Should there be some rollback or tax recapture program if the land is not 
kept in that use classification for some specified period of time if a conservation land use classification is adopted and taxes are reduced for landowners? Questions such as these may help you determine whether you support the amendment.

\section{Summary}

Adoption of the constitutional amendment requires a vote in favor of the amendment by a minimum of $60 \%$ of those voting. Additionally, amendments are subject to legal challenges and could possibly be removed from the ballot if successfully challenged.

Voters in Florida have the opportunity to change the state constitution during the 2008 general election. The intent and purpose of the information contained in this fact sheet on Amendment No. 4 is not to tell individuals how to vote. Rather, the fact sheet is provided to help voters become more informed. Informed voters need to be more knowledgeable of the ballot issue on which they are voting than just by reading a ballot title and ballot summary. Ballot titles and summaries do not inform voters in significant detail, nor do they inform voters on policy implications of what a yes or no vote implies. Because informed voters make informed public policy decisions, your challenge as a voter and a citizen is to become informed and then, by casting your ballot, make your values and preferences known.

\section{References}

Florida Department of State, Division of Elections. 2008. Initiatives / Amendments / Revisions. Division of Elections, Florida Department of State, Tallahassee, FL (May). http://election.dos.state.fl.us/initiatives/ initiativelist.asp

Florida Taxation and Budget Reform Commission. 2008. A resolution proposing an amendment to Sections 3 and 4 of Article VII and the creation of Section 28 of Article XII of the State Constitution to require the Legislature. TBRC, Tallahasse, FL (May). http://www.floridatbrc.org/pdf/CP15 16Final2.pdf
Florida Taxation and Budget Reform

Commission. 2008. Staff Analysis and Economic Impact Statement. TBRC, Tallahassee, FL (May). http://www.floridatbrc.org/pdf/ CSforCP0015AnalysisSD3_31_08.pdf

Florida Taxation and Budget Reform Commission. 2008. Transmittal letter. TBRC, Tallahassee, FL (May). http://www.floridatbrc.org/pdf/ CPTransmittalLetter.pdf 